Pesq. Vet. Bras. 37(9):911-915, setembro 2017

DOI: $10.1590 / \mathrm{S} 0100-736 \mathrm{X} 2017000900002$

\title{
Degenerative axonopathy associated with copper deficiency in pigs ${ }^{1}$
}

\author{
Roberio G. Olinda² ${ }^{2 *}$ Lisanka A. Maia², Maria T.S. Frade², Mauro P. Soares ${ }^{3}$, Severo S. \\ Barros $^{3}$, David Driemeier ${ }^{4}$, Franklin Riet-Correa ${ }^{2}$ and Antônio F.M. Dantas ${ }^{2}$
}

\begin{abstract}
Olinda R.G., Maia L.A., Frade M.T.S., Soares M.P., Barros S.S., Driemeier D., Riet-Correa F. \& Dantas A.F.M. 2017. Degenerative axonopathy associated with copper deficiency in pigs. Pesquisa Veterinária Brasileira 37(9):911-915. Programa de Pós-Graduação, em Medicina Veterinária, Hospital Veterinário, Centro de Saúde e Tecnologia Rural, Universidade Federal de Campina Grande, Campus de Patos, Patos, PB 58700-000, Brazil. E-mail: rgumes@hotmail.com

The epidemiological, clinic and morphological (pathological and ultrastructural) aspects of four outbreaks of copper deficiency affecting 21- to 90-day-old pigs in the Northeast region of Brazil are reported. Clinical signs began with paraparesis and ataxia and progressed to flaccid or spastic paralysis of the pelvic and thoracic limbs, followed by sternal and/or lateral recumbence. In addition, some animals showed dog-sitting position and intention tremors. The clinical manifestation period was 5-20 days. Significant gross lesions were not observed; however, microscopically, symmetrical degeneration of the white matter with ballooned myelin sheaths containing occasional macrophages was observed, mainly in the spinal cord. Two pigs presented with necrosis ad loss of Purkinje cells and ectopic Purkinje cells in the granular layer and cerebellar white matter. A ultrastructural analysis showed different degrees of damage of myelinated axons in the spinal segments, including an absence of the axoplasm structures with only axonal residues remaining. The myelin sheaths were degenerated and often collapsed into the space previously occupied by the axon. These results suggest that myelin degeneration is secondary to the axonal lesion. Finally, the concentration of copper in the liver was determined using atomic absorption spectrophotometry and was found to be low (ranging from 2.2 to $10.8 \mathrm{ppm}$ ). In conclusion, in the Brazilian semiarid region, Cu deficiency occurs in 21 to 90 -day-old pigs that ingested different types of waste in their food.
\end{abstract}

INDEX TERMS: Degenerative myelopathy, axonal degeneration, myelin degeneration, copper deficiency, mineral deficiency, swine.

RESUMO.- [Axonopatia degenerativa associada com deficiência de cobre em suínos.] São relatados os achados epidemiológicos, clínicos e morfológicos (patológicos e ul-

\footnotetext{
${ }^{1}$ Received on May 29, 2016.

Accepted for publication on November 11, 2016.

${ }^{2}$ Programa de Pós-graduação em Medicina Veterinária, Hospital Veterinário, Centro de Saúde e Tecnologia Rural, Universidade Federal de Campina Grande (UFCG), Campus de Patos, Patos, PB 58700-000, Brazil. *Corresponding author: rgumes@hotmail.com

${ }^{3}$ Laboratório Regional de Diagnóstico, Faculdade de Veterinária (FV), Universidade Federal de Pelotas (UFPel), Campus Universitário s/n, Pelotas, RS 96015-560, Brazil.

${ }^{4}$ Departamento de Patologia Clínica Veterinária, Faculdade de Veterinária, Universidade Federal do Rio Grande do Sul (UFRGS), Av. Bento Gonçalves 9090, Porto Alegre, RS 95320-000, Brazil.
}

traestruturais) de quatro surtos de deficiência de cobre em suínos afetados entre 21 e 90 dias de idade na região Nordeste do Brasil. Os sinais clínicos iniciaram com paraparesia e ataxia, que progrediu a paralisia flácida ou espástica dos membros pélvicos e torácicos, seguido de decúbito esternal e/ou lateral. Além disso, alguns animais apresentaram posição de cão sentado e tremores de intenção. 0 período de manifestação clínica variou de 5-20 dias. Não foram observadas lesões macroscópicas significativas; no entanto, microscopicamente, foi observada degeneração simétrica da substância branca com fragmentação das bainhas de mielina, contendo ocasionais macrófagos, principalmente na medula espinal. Dois suínos apresentaram necrose e perda de células de Purkinje e células de Purkinje ectópicos na camada granular da substância branca cerebelar. A aná- 
lise ultraestrutural mostrou diferentes graus de lesões em axônios mielinizados em segmentos da medula espinhal, incluindo o desaparecimento de estruturas do axoplasma, restando apenas restos axonais. A bainha de mielina encontrava-se degenerada e muitas vezes, colapsada dentro do espaço previamente ocupado pelo axônio. Esses resultados sugerem que a degeneração da mielina é secundária à lesão axonal. Finalmente, a concentração do cobre no fígado foi determinada usando espectrometria de absorção atômica e revelou baixos valores (variando de 2,2-10,8ppm). Conclui-se que na região semiárida do Brasil ocorre deficiência de cobre em suínos de 21 a 90 dias de idade alimentados com diferentes tipos de resíduos.

TERMOS DE INDEXAÇ̃̃O: Mielopatia, degeneração axonal, degeneração da mielina, deficiência de cobre, deficiência mineral, suínos.

\section{INTRODUCTION}

Copper $(\mathrm{Cu})$ is a trace element that is essential for the normal development and functioning of the nervous system. It is involved in various enzymatic reactions and is a structural component of many enzymes (Zachary \& McGavin 2013). The neurologic manifestations of copper deficiency in ruminants are well known. The clinical signs of copper deficiency are characterized by lower motor neuron impairment and include progressive paraparesis and ataxia in the hind limbs, which usually results in tetraparesis or paralysis. Microscopic lesions in the central nervous system, and specifically in the spinal cord, are also associated with copper deficiency and include axonopathy with occasional neuronal necrosis and demyelination secondary to axonal damage (Cantile \& Youssef 2016).

Copper deficiency with neurological manifestations (Wilkie 1959) caused by demyelination in the spinal cord (Guedes et al. 2014) that extends to the cerebellum (McGavin et al. 1962, Cancilla \& Barlow 1970) and brainstem (Guedes et al. 2014) with ataxia and low copper concentrations in the liver (Guedes et al. 2014) has been occasionally reported in young pigs.

In Brazil, neurological disorders caused by copper deficiency have been reported in bovines (Riet-Correa et al. 1993), sheep (Guedes et al. 2007), goats (Guedes et al. 2007, Silva et al. 2014) and pigs (Guedes et al. 2014). This study describes the epidemiological, clinical, pathological and ultrastructural findings of neurological disease caused by copper deficiency in pigs in the Northeast region of Brazil.

\section{MATERIALS AND METHODS}

The data included in this study were obtained through a prospective analysis of suspected cases of $\mathrm{Cu}$ deficiency diagnosed in pigs between March 2013 and October 2015 at the Animal Pathology Laboratory in the Veterinary Hospital of the Federal University of Campina Grande (UFCG). During the occurrence of outbreaks (total number of 4), visits were made to farms to collect epidemiological data and information relating to clinical signs.

Nine necropsies were performed and samples were collected from the organs of the thoracic and abdominal cavities. In addition, the entire central nervous system (CNS) was fixed in $10 \%$ buffered formalin. Transverse sections of the cerebral cortex, basal ganglia, thalamus, hippocampus, rostral colliculus, caudal colliculus, ponds, cerebellum, obex and medulla oblongata as well as transverse and longitudinal sections of the cervical, thoracic and lumbar cord were embedded in paraffin, cut at 4-6 $6 \mathrm{~m}$, and stained by hematoxylin and eosin. Selected sections of the brain and spinal cord were also stained with Luxol Fast Blue myelin stain.

For transmission electron microscopy, sections of the cerebral cortex, cerebellum and spinal cord were fixed in $2.5 \%$ glutaraldehyde and post-fixed in $1 \%$ osmium tetroxide. The sections were dehydrated in increasing concentrations of ethanol and embedded in Epon. The ultra-thin sections were stained using uranyl acetate and lead citrate and examined with a transmission electron microscope (Zeiss 109).

Liver samples from six pigs were fixed in buffered formalin and sent to the Atomic Absorption Laboratory of the Federal University of Rio Grande do Sul to determine the concentration of copper using atomic absorption spectrometry.

\section{RESULTS}

Four outbreaks of copper deficiency were observed between 2013 and 2015 and affected 21- to 90-old-day pigs from different breeds (Table 1). The farm location, date of the outbreak and number of pigs affected are listed in Table 1. In outbreaks 1 (pigs 1 and 2) and 3 (pig 4), the pigs were fed with corn bran and large amounts of whey obtained from cheese production. In outbreak 2 (pig 3) and 4 (pigs 5 and 6), the pigs were fed corn meal and cooked food scraps.

All of the affected pigs were born normal. Clinical signs began with paraparesis and mild ataxia and progressed to severe flaccid or spastic paralysis of the hind and forelimbs. In addition, some animals adopted a dog-sitting position (Fig.1). Intention tremors, muscle atrophy of the hind limbs, and sternal or lateral recumbence were also observed. Consciousness, food and water intake, and body tempera-

Table 1. Epidemiological data, clinical course and the concentration of copper $(\mathrm{Cu})$ in the liver of pigs with copper deficiency in the Northeast of Brazil

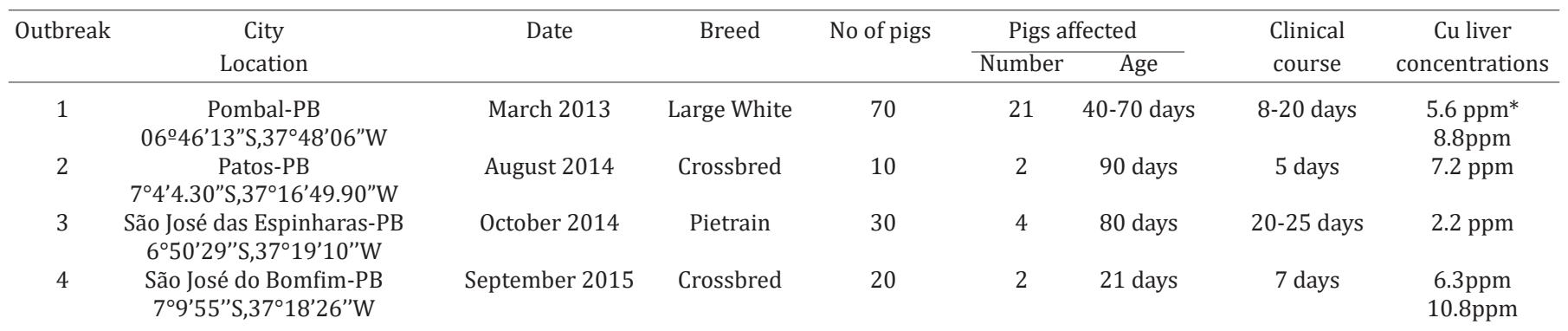

Each value corresponds to one pig liver examined. *Reference values (60-117ppm). 
ture were normal. The clinical manifestation period and the concentrations of $\mathrm{Cu}$ in the liver are shown in Table 1.

Postmortem findings included skin bruising in three animals (pigs 1, 6 and 7) and hyperextension of the forelimbs in pigs 8 and 9. In all of the pigs, a histological examination of the spinal cord showed bilateral and symmetrical focally extensive vacuolation of the periaxonal space and occasional axonal spheroids. The myelin sheaths were fragmented with vacuoles of different sizes, which sometimes formed digestion chambers containing macrophages (Fig.2), particularly in the ventral and lateral funiculus. There was also a slight infiltration of lymphocytes and histiocytes in the neuropil and the meninges, which was more evident in the thoracic and lumbar spinal cord (pigs 1, 2 and 3). Myelin degeneration with vacuolation and oc-

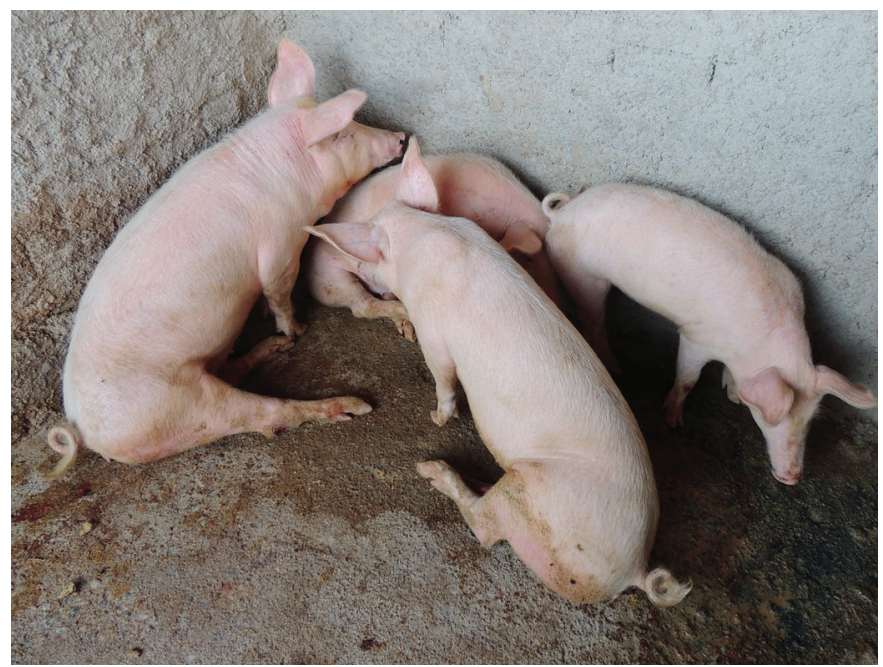

Fig.1. Pigs from farm 1 outbreak in Pombal. Showing paraparesis (dog-sitting position) due to with copper deficiency.

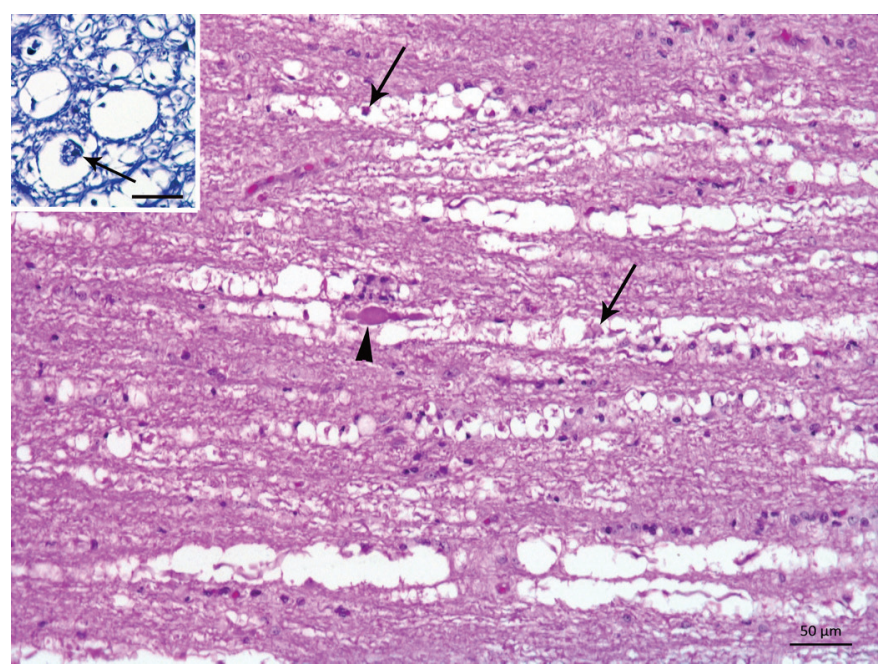

Fig.2. Pig from farm 1 outbreak in Pombal. Spinal cord showing myelin vacuolization of the white matter with presence of macrophages or axonal residues within the vacuoles (arrows). An axonal spheroid is also observed (arrowhead). HE, Bar = $50 \mu \mathrm{m}$. Inset, transversal section of the spinal cord showing vacuoles containing axonal residues, that are being phagocytosed (arrow). Luxol Fast Blue, Bar $=20 \mu \mathrm{m}$.

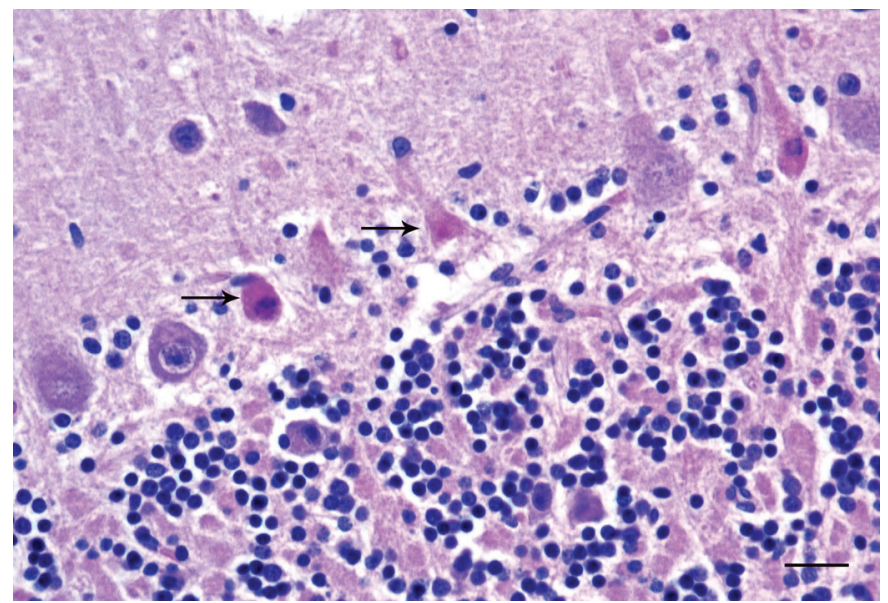

Fig.3. Pig from farm 3 outbreak in São José do Bomfim. Cerebellum showing necrosis of Purkinje cells (arrows) HE, Bar $=20 \mu \mathrm{m}$.

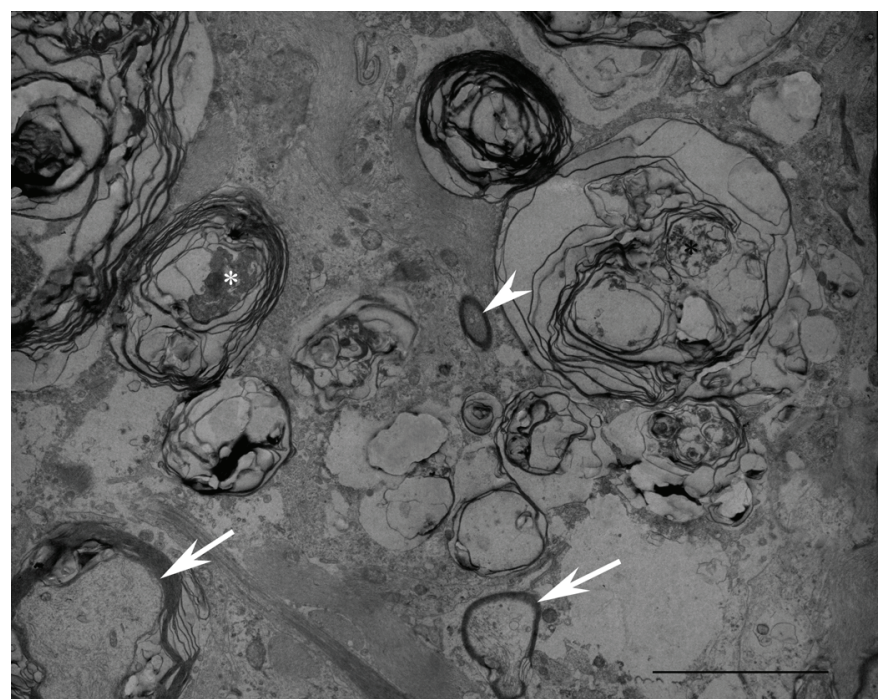

Fig.4. Transmission electron microscopy. Pig from farm 4 outbreak São José de Espinharas. Spinal cord. Several degenerated and collapsed myelin lamellae (arrows) with disappearance of the axon. Degenerated myelin sheath are also observed (asterisk). A small axon apparently not damage is seen (arrowhead). $\operatorname{Bar}=5 \mu \mathrm{m}$.

casional spheroids were also observed in the ventral nerve roots. Luxol Fast Blue staining revealed a significant loss of myelin in the spinal cord segments, especially in the ventral horn near the median cleft (Fig.2, inset). Multifocal areas of mild myelin degeneration were also observed in the brainstem of all pigs.

Multifocal necrosis and a loss of Purkinje cells were observed in the cerebellum (Fig.3). A rarefaction of the granular layer with the presence of ectopic Purkinje cells was also observed. Moderate vacuolation with gliosis was seen in the molecular layer. Multiple neuronal cell bodies (many of them degenerated), which are characteristic of neuronal dysgenesis, were observed in the white matter.

The ultrastructural analysis of segments of the cervical and thoracic spinal cord revealed different degrees of damage in myelinated axons. Some showed disappearance of axoplasm structures, remaining only in some segments 
remnants of axoplasm with finely granular aspect. In other segments, the axons were not observed within the myelin sheaths. The myelin sheaths were degenerated, collapsed and filling the space previously occupied by the axon (Fig.4). In several segments there were macrophages phagocytosing cell debris and damaged axons.

\section{DISCUSSION}

The diagnosis of $\mathrm{Cu}$ deficiency was based on epidemiological, clinic and morphological (pathological and ultrastructural) findings and by the detection of low $\mathrm{Cu}$ concentrations in the liver samples. The clinical and pathological findings reported in this study are similar to those reported in spontaneous (Wilkie 1959, McGavin et al. 1962, Guedes et al. 2014) or experimental (Cancilla \& Barlow 1970) $\mathrm{Cu}$ deficiency in pigs.

In all of the outbreaks, the food supplied to the pigs consisted of corn meal, food scraps and whey, which is not suitable for pigs of this age group and leads to copper deficiency. The influence of diet on the occurrence of copper deficiency in pigs has been previously reported in pigs that exhibited neurological deficits and low liver levels of copper (McGavin et al. 1962). In the outbreaks observed in northeastern Brazil, the pigs were born normal and began displaying clinical signs of deficiency between 21 and 90 days of age. In previous reports of copper deficiency in swine, piglets (up to 150 days of age) were also affected (McGavin et al. 1962, O’Hara \& Shortridge 1966, Pletcher \& Banting 1983, Guedes et al. 2014).

$\mathrm{Cu}$ is essential for the normal development and functioning of the nervous system and Cu deficiency in the diet causes congenital and acquired anomalies of the nervous system in animals and humans (De Lahunta \& Glass 2009). Although the biochemical mechanism of $\mathrm{Cu}$ deficiency in the nervous system is not entirely known, it is suggested that a reduction in the activity of cuproenzymes results in changes in the metabolic pathways that contain these enzymes and contributes to the onset of the lesions (Cantile \& Youssef 2016).

The symmetrical and progressive clinical signs of lower motor and cerebellar impairment (starting with ataxia and paresis in the hind limbs and progressing to flaccid paralysis and intention tremors) reported in this study are similar to the clinical signs previously reported in pigs (McGavin et al. 1962, Guedes et al. 2014), lambs and young goats (Summers et al. 1995) with copper deficiency. However, other clinical signs, including spasticity, may be due to upper motor neuron damage (De Lahunta \& Glass 2009).

The microscopic findings in the spinal cord and brainstem are similar to findings previously reported in pigs (McGavin et al. 1962, Cancilla \& Barlow 1970, Guedes et al. 2014). In addition to myelin degeneration observed in both swine and ruminants, chromatolysis and occasional neuronal necrosis are clinically observed in small ruminants (Santos et al. 2006, Guedes et al. 2007, Silva et al. 2014) and are not observed in pigs, which show lesions restricted to white matter more closely surrounding the ventral and lateral funiculus of the spinal cord. The ultrastructural analysis showed that the primary lesion involve axonal degeneration, and the myelin vacuolization observed in the spinal cord represent foci of periaxonal demyelination, which is similar to findings by O'Hara \& Shortridge (1966) and Guedes et al. (2014).

The histological changes observed in the cerebellum of these pigs have not been previously reported in swine and are similar to those described in enzootic ataxia of goats (Banton et al. 1990, Cantile \& Youssef 2016). These lesions are attributed to a biochemical disorder in cerebellar development and are caused by the absence of energy generation, and a consequent inhibition of aerobic metabolism and decreased phospholipid synthesis (Zachary \& McGavin 2013).

In spontaneous cases of $\mathrm{Cu}$ deficiency in pigs, the $\mathrm{Cu}$ concentrations in the liver range from 3 to $10 \mathrm{ppm}$ (McGavin et al. 1962, Munday 1967, Guedes et al. 2014), which is consistent with the liver $\mathrm{Cu}$ concentrations observed in the liver samples collected in this study. In addition, the $\mathrm{Cu}$ concentrations in the liver are a reliable indicator of $\mathrm{Cu}$ deficiency when there are clinical signs associated with histologic lesions involving axonal and myelin degeneration, especially in the white matter of the spinal cord. When pigs receive a diet containing adequate amounts of $\mathrm{Cu}$, the average $\mathrm{Cu}$ concentration in the liver is approximately $117 \mathrm{ppm}$ (Cancilla et al. 1967).

The differential diagnosis includes pantothenic acid deficiency, botulism, rabies, medullar abscesses, and selenium poisoning. In swine, pantothenic acid deficiency causes histologic lesions similar than copper deficiency; however, the low copper concentrations in the liver and the electron microscopy allowed the differentiation between both deficiencies. Pantothenic acid deficiency affects the myelin sheath, while in $\mathrm{Cu}$ deficiency the lesion affects primary the axon and secondary the myelin sheath (De Lahunta \& Glass 2009). Botulism causes flaccid paralysis and there are no gross or histologic lesions(Raymundo et al. 2012). In rabies there is a non-suppurative encephalomyelitis associated with intracytoplasmatic inclusion bodies (Pessoa et al. 2011). Medullar abscesses generally affect one or few pig and there is a suppurative myelitis(De Lahunta \& Glass 2009). In selenium poisoning there is a symmetric polyoencephalomalacia and foot lesions (Gomes et al. 2014). The epidemiologic data as well as the microscopic and electron microscopy exams allowed rule out those diseases. Otherwise, the very low copper concentrations in the liver confirm copper deficiency.

\section{CONCLUSIONS}

In the Brazilian semiarid region, $\mathrm{Cu}$ deficiency occurred in 21 to 90-day-old pigs that ingested different types of waste in their food.

The clinical signs of $\mathrm{Cu}$ deficiency included progressive ataxia, paresis and intention tremors due to degenerative axonopathy, which is followed by secondary myelin degeneration in the white matter of the spinal cord, neuronal degeneration and necrosis of the Purkinje cells of the cerebellum.

Acknowledgments.- This research was financially supported by the CNPq/Universal (427840/2016-3). 


\section{REFERENCES}

Banton M.I., Lozano-Alarcon F., Nicholson S.S., Jowett P.L., Fletcher J. \& Olcott B.M. 1990. Enzootic ataxia in Louisiana goat kids. J. Vet. Diagn. Invest. 2:70-73.

Cancilla P.A., Barlow R.M., Weissman N., Coulson W.F. \& Carnes W.H. 1967. Dietary production of congenital copper deficiency in swine. J. Nutr. 93:438-444.

Cancilla P.A. \& Barlow R.M. 1970. Experimental copper deficiency in miniature swine, biochemistry, histochemistry and pathology of the central nervous system. J. Comp. Pathol. 80:315-319.

Cantile C. \& Youssef S. 2016. The nervous system, p.381-385. In: Maxie M.G. (Ed.), Jubb, Kennedy and Palmer's Pathology of Domestic Animals. Vol.1. 6th ed. Elsevier Saunders, Philadelphia.

De Lahunta A. \& Glass E. 2009. Veterinary Neuroanatomy and Clinical Neurology. 3rd ed. W.B. Saunders, St Louis, p.540.

Gomes D.C., Souza S.O., Juffo G.D., Pavarini S.P. \& Driemeier D. 2014. Intoxicação por selênio em suínos no Sul do Brasil. Pesq. Vet. Bras. 34:1203-1209.

Guedes K.M.R., Perecmanis S., Arruda L.F., Mustafa V.S. \& Castro M.B. 2014. Deficiência de cobre em suínos: caracterização clínico-patológica. Ciência Rural 44:1264-1267.

Guedes K.M.R., Riet-Correa F., Dantas A.F.M., Simões S.V.D., Miranda Neto E.G., Nobre V.M.T. \& Medeiros R.M.T. 2007. Doenças do Sistema nervoso central, em caprinos e ovinos no semi-árido. Pesq. Vet. Bras. 27:29-38.

McGavin M.D., Ranby PD. \& Tammemagi L. 1962. Demyelination associated with low liver copper levels in pigs. Aust. Vet. J. 38:8-14.

Munday B.L. 1967. Diseases of the central nervous system of pigs in Tasmania. Aust. Vet. J. 43:374-378.
O'hara P.J. \& Shortridge E.H. 1966. Some diseases of the porcine central nervous system in New Zealand. N.Z. Vet. J. 14:1-12.

Pessoa C.R.M., Silva M.L.C.R., Gomes A.A.B., Garcia A.I.E., Ito F.H., Brandão P.E. \& Riet-Correa F. 2011. Paralytic rabies in swine. Braz. J. Microbiol. 42:298-302.

Pletcher J.M. \& Banting L.F. 1983. Copper deficiency in piglets characterized by spongy myelopathy and degenerative lesions in the great blood vessels. J. S. Afr. Vet. Assoc. 54:45-46.

Raymundo D.L., Gomes D.C., Boabaid F.M., Colodel E.M., Schmitz M., Correa A.M.R., Dutra I.S. \& Driemeier D. 2012. Type C botulism in swine fed on restaurant waste. Pesq. Vet. Bras. 32:1145-1147.

Riet-Correa F., Bondan E.F., Mendez M.C., Moraes S.S. \& Concepción M.R. 1993. Efeito da suplementação com cobre e doenças associadas à carência de cobre em bovinos no Rio Grande do Sul. Pesq. Vet. Bras. 13:45-49.

Santos N.V.M., Souza J.E., Guerra S.J.L., Maiorka P.C., Hortelani M.A., Silva F.F. \& Ortolani E.L. 2006. Avaliação epidemiológica, clínica, anatomopatológica e etiológica de surtos de ataxia em cabritos e cordeiros. Ciência Rural 36:1207-1213.

Silva T., Aguiar G., Carvalho F., Simões S., Miranda Neto E., Dantas A., Soares P. \& Riet-Correa F. 2014. Outbreaks of copper deficiency in ruminants in the semiarid region of Paraíba, Brazil. Semina, Ciênc. Agrárias 35:19551960.

Summers B.A., Cummings J.F. \& De Lahunta A. 1995. Veterinary Neuropathology. Mosby, St Louis, MO. 527p.

Wilkie W.J. 1959. Mineral deficiencies in pigs. Aust. Vet. J. 35:209-216.

Zachary J.F. \& Mcgavin M.D. 2013. Bases da Patologia Veterinária. 4르 ed. Elsevier, Rio de Janeiro. 1476p. 